This is an Accepted Manuscript of an article published by Taylor \& Francis in Historical Journal of Film, Radio and Television on 17/08/17, available online: https://www.tandfonline.com/doi/full/10.1080/01439685.2017.1331630 


\title{
THIS FILM IS RESTRICTED: THE TRAINING FILMS OF THE BRITISH SECURITY SERVICE
}

\author{
Dr Shane O'Sullivan (Kingston University)
}

School of Performance and Screen Studies

Penrhyn Road

Kingston upon Thames

Surrey KT1 2EE

Tel: 02084179000 ext: 67091

Mob: 07931107944

email: S.Osullivan@kingston.ac.uk 


\section{Abstract}

In 1962, following a series of spy scandals, the Security Service and the Central Office of Information (COI) created a security education campaign to raise awareness of the Soviet espionage threat to state and industrial secrets, and to provide security training for military and civilian personnel handling classified material. Several instructional films were commissioned, using fictional scenarios to dramatize the Cold War threat to security personnel. This paper will examine four of these declassified and highly inventive films - It Can't Happen to Me (1962), Persona Non Grata (1964) and The Lecture (1968), produced by James Carr's World Wide Pictures; and Any One of Us (1970), directed by Seafield Head for Verity Films. Drawing on COI production files at the National Archives and the films themselves, I explore the making and underlying message of these long-neglected and highly stylized pieces of Cold War propaganda; how they anticipate key texts of the sixties spy genre like The Spy Who Came in from the Cold (1965); and how they compare to American security education films from the same period.

\section{Keywords}

MI5, training films, security education, espionage, spy fiction 
Christopher Andrew's authorized history of Britain's domestic Security Service better known as MI5 - devotes a chapter to a series of spy scandals during Macmillan's second term as Prime Minister in the early 1960s, which led him 'to warn the House that hostile intrigue and espionage are being relentlessly maintained on a large scale.' 1

On 7 January 1961, five arrests were made in the Portland spy ring. Two clerks at the Admiralty Underwater Weapons Establishment at Portland, Harry Houghton and Ethel Gee, were having an affair and she had access to top-secret documents he was passing to a 'deep-cover' KGB agent by the name of 'Gordon Lonsdale'. One of MI5's primary functions was counterespionage and a surveillance team tailed Lonsdale to the Ruislip bungalow of Peter and Helen Kroger, who acted as his radio operators and technical support team. As Andrew notes, the Krogers' fingerprints unmasked them as 'veteran American KGB illegal agents Morris and Lona Cohen' and Lonsdale was identified as Soviet illegal Konon Molody and deported in a spy exchange in $1964 .^{2}$

After the five spies were convicted in March 1961, Sir Charles Romer was appointed to chair a Committee of Inquiry into the case - the first major counterespionage inquiry since the disappearance of Burgess and Maclean ten years earlier. ${ }^{3}$

On 5 April 1961, MI6 officer George Blake confessed he had been spying for the KGB since his release from a Korean prison in 1953. The resulting trial prompted further public alarm and government disquiet and after 'reviewing what further measures should be taken to protect the security of the realm', Macmillan announced 'a fresh review [of] security procedures and practices...throughout the 
public service. ${ }^{4}$ A new tribunal of inquiry, chaired by Lord Radcliffe, one of Britain's most eminent judges, would investigate the Blake case and review Romer's findings on the Portland case, which highlighted poor security at the Admiralty. ${ }^{5}$

The Radcliffe Report (1962) stressed 'the biggest single risk to security at the present time is probably a general lack of conviction that any substantial threat exists. This attitude of mind can be overcome only by a sustained and skillfully directed educational effort...designed primarily to give security staff an insight into the nature of the various threats to security... and to instruct them in the necessary techniques [to counter them]. ${ }^{6}$

The Security Service was asked to provide government departments with 'advice on training techniques and...suitable material for talks and lectures' and the report stressed that such material 'should convey an adequate sense of reality to every listener':

Hitherto effective education has been handicapped by the fact that the subject tends itself to be regarded as secret. The average Civil Servant, even in a Defence Department, has little conception of the extent and intensity of the effort to penetrate his secrets and probably knows next to nothing of the existence or activities of the Security Service. When something dramatic happens, as in the Portland case, the whole subject springs momentarily to life: but for the rest it seems remote and unreal. If he is to remain constantly on the alert in security matters he will have to be brought more into touch with what goes on and...something more of the 
traditional veil will have to be lifted. ${ }^{7}$

On 5 April 1962, Macmillan accepted Radcliffe's recommendations and promised to implement them 'as rapidly as possible.'8 Andrew's history of MI5 does not mention the subsequent security education campaign devised by the Security Service and the Central Office of Information (COI) to increase awareness of the Soviet espionage threat 'among civil servants with access to classified material...[and] people in industry engaged on secret Government contracts' - a campaign in which training films played a key role. ${ }^{9}$

As James Chapman notes, the COI serviced the publicity needs of government departments by commissioning films and other media on their behalf. ${ }^{10}$ The COI had just completed It Can't Happen to Me (1962), a film on industrial security for the Ministry of Aviation, and now worked on a new series of security education materials with the Security Service, sponsored by the Treasury - the department responsible for training in the Civil Service.

After a long development period, one hundred thousand copies of a $60-$ page booklet 'Their Trade is Treachery' were distributed 'for Official Use Only' within the civil service in 1964; as well as a training film, Persona Non Grata (1964), using fictional scenarios to dramatize the Cold War threat to security personnel; and a series of posters in over a hundred designs with the tagline 'Keep Our Secrets Secret'.

Two more training films followed - The Lecture (1968) and Any One of Us (1970) - and this paper will draw on COI production files for three of the films, and the films themselves, to explore how they were made; how they sit alongside 
film and television representations of spying; and how they compare to American security education films from the same period.

\section{The Spy Film}

Alfred Hitchcock's spy thrillers of the thirties and forties implanted 'the spy/secret agent narrative' in the British psyche, a genre characterized by James Chapman as involving 'all manner of cloak-and-dagger intrigue (spying, sabotage, espionage, counter-espionage, theft of state or industrial secrets, political assassination)... [and] generally...the uncovering of a conspiracy plot that threatens the security of the state or its relations with other states. ${ }^{11}$

As Chapman notes, state-sponsored films designed to increase public awareness of the espionage threat from enemy agents can be traced back to three 'anti-gossip' films made by Ealing Studios for the Ministry of Information's 'Careless Talk Costs Lives' campaign in 1940: All Hands, Dangerous Comment and Now You're Talking. These short thrillers dramatized stories of German spies and saboteurs overhearing 'careless talk' from sailors, RAF personnel and factory workers and using leaked information to attack the enemy. ${ }^{12}$

Anthony Aldgate and Jeffrey Richards document how Ealing went on to produce The Next of Kin (1942), a very successful feature on the theme for the War Office ${ }^{13}$ and the U.S. War Department commissioned its own anti-gossip training films, such as Don't Talk (1942), produced by MGM and dramatizing an FBI case of domestic espionage.

The American Department of Defense (DOD) commissioned ten training films on industrial security between the mid-fifties and late sixties, 
primarily aimed at employees with access to classified information at various defence contractors. The first of these, The Case of Comrade $T$ (1956), produced by Warner-Pathe, depicts a communist spy berated by his case officers for three cases in which his attempts to infiltrate an electronics firm, an aircraft factory and a chemical plant were thwarted by alert staff and tight security. ${ }^{14}$

But in the UK, despite extensive scholarship on wartime propaganda films, only James Humphreys' case study of the government response to the spy scandals of the sixties briefly mentions the British use of state-sponsored training films in security education in the later Cold War period and this is the first paper, to my knowledge, to discuss the training films of the Security Service in any detail. $^{15}$

While it's difficult to pinpoint stylistic influences on the directors of the COI training films, as they are all now dead, the proliferation of spy series on British television during this period clearly had an influence. After Hitchcock's roaring return to the spy genre with North by Northwest (1959), the BBC resurrected Harry Lime in the Third Man TV series (1959-60) and followed a Dutch interrogator's search for enemy spies among wartime refugees to Britain in Spycatcher (1959-61).

But, as Chapman notes, Danger Man, first broadcast in September 1960, was the spy series that launched 'the new vogue for secret agent dramas' that would dominate the sixties television landscape on both sides of the Atlantic. Patrick McGoohan starred as 'Drake, John Drake' - an Irish-American secret agent for NATO in the first series, and a British agent for ' $\mathrm{M} .9$ ' thereafter. Counterintelligence was a regular theme, with an early episode ('The Key') based 
around a security leak at the U.S. embassy in Vienna. ${ }^{16}$

The first series of The Avengers followed in January 1961, introducing

John Steed as 'a shady secret agent figure' fighting organized crime. By now, Ian Fleming's Bond novels had captured the public imagination and in March 1961, President Kennedy admitted to Life magazine that From Russia with Love was one of his favourite books, but the first Bond film, Dr. No (1962) was still eighteen months away. ${ }^{17}$

\section{Inside the COI}

The COI's Film and Television Division oversaw the production of the security education films and had two main production areas, according to John Hall, a former Director:

One was devoted to producing largely television series for the Overseas Information Services and funded by the Foreign Office and the Commonwealth Relations Office. The other production area was the Home Film Production, which made films for all the other departments of government including the Ministry of Defence...Production staff of the Overseas Services were mainly producers/directors/writers making programmes, whereas most of the staff on the Home Production were...Production Control Officers (PCOs) whose function was to act as gobetweens linking the sponsoring department and documentary film company commissioned by COI. Thus, for a given film, the security service would have contacted COI Films Division via the Head of Home Production 
at that time, Frances Cockburn (who had been, as I was a bit later, positively vetted). She and Annis James [who later worked for Hall] as a Senior PCO would have been initially briefed by the security service about the purpose of the film and available budget...[and] a number of "points to be covered."18

Annis James was one of six PCOs in Home Film Production and the officer in charge of the first three security training films. She remembers working on the classified films was 'more cagey than the normal ones'. The sponsor would visit $\mathrm{COI}$ and spend a couple of hours discussing the brief - what result they wanted, what they did not want and the intended audience. The films had to be scripted as the classified content was tightly controlled, so she would choose a production company that suited the subject - in this case, World Wide Pictures, a regular supplier and where Frances Cockburn had started off as an editor before joining the $\mathrm{COI}$ in the mid-fifties. ${ }^{19}$

In the summer of 1962, the Foreign Office commissioned a detailed study from the Security Service on 'a new subject of considerable importance and delicacy... namely possible Communist penetration of the Independent Television Companies...' Biographical information was checked against existing records and at least one Communist was found, so we can be sure World Wide and its crew were all vetted by the sponsor before production, unless already cleared on a previous restricted film. ${ }^{20}$

The PCO commissioned treatments and scripts and supervised production. The sponsor would approve the treatment and script before production, and give 
notes on a rough cut of the film before viewing a master cut for final approval. ${ }^{21}$

\section{It Can't Happen to Me (1962)}

$\mathrm{COI}$ production files at the National Archives date the initial treatment for the first training film on security education - then titled 'Stranger than Fiction' - to 7

September 1960. The 'aim of the film' set out in the treatment gives us a sense of the original brief:

In time of war, the threat to security from enemy espionage is a fact that is obvious to everyone.... In time of peace, war is an unpleasant matter which people wish to thrust to the back of their minds, and spies are the subject of 'escapist' books and films. But without the realisation...that espionage is a living, ever-present danger and not a remote and nebulous possibility, security regulations will remain fussy and obstructive precautions to be honoured only in the letter...The object of the film...is to bring home to its audience, first, the vigilance and activity of enemy espionage and, second, the real necessity for taking their security regulations extremely seriously. ${ }^{22}$

While this was written four months before the arrests in the Portland spy ring, MI5 already had the principals under surveillance - acting on information from Polish triple-agent Michael Goleniewski, who would soon defect to the CIA - and industrial security was clearly a concern. ${ }^{23}$

The treatment was written by Malcolm Stewart, a freelancer for World Wide Pictures, who pitched the film as a 'T.V. play where the action is mainly played within a given number of sets and the message is largely conveyed through 
dialogue and careful observation of peoples' reactions.' A shooting script was commissioned on 20 October 1960 for the sum of $£ 175$.

Stewart delivered a further treatment on 22 February 1961, titled 'It Might Have Been You - a film on Industrial Security' but the writing process was evidently longer and more complicated than usual, as World Wide asked the COI for an additional $£ 100$ for the writer before delivering the second draft:

Owing to the very nature of the subject, it was essential that the scriptwriter work in very much closer contact with the sponsor than is normal [and] when the script had eventually been written, substantial alterations were required which will involve a re-write of a considerable part of the script.

While the Radcliffe inquiry was still sitting, It Can't Happen to Me was finally commissioned by Annis James on 11 August 1961 under the working title 'Industrial Security.' The budget was $£ 8,846$ - modest compared to the $£ 25,000$ per episode ITC spent on the first series of The Saint the following year. ${ }^{24}$

The film was directed by Henry Cass - best known for horror films like Blood of the Vampire (1958) - and approved and ready for restricted $16 \mathrm{~mm}$ distribution within the Civil Service on 28 February 1962. The film ran 27 minutes and the final synopsis reads:

This is the story, based on fact, of how an unsuspecting person can be drawn into a dangerous and unpleasant way of life by a net of blackmail, flattery and bribery. A man can be caught up in the melodramatic world of espionage, almost before he realizes he is acting contrary to the Official 
Secrets Act, through the insidious influence of another seemingly decent citizen, until he finds it is too late to back out. The film underlines the fact that maintaining national security in peacetime is a very serious job and that special care and full co-operation are essential. ${ }^{25}$

In style, this is the least adventurous of the four training films and a fairly literal and undramatic translation of the brief. We open on a car passing through a security checkpoint at a factory gate as the camera pans to a poster of the Official Secrets Act. A narrated sequence introduces 'what security men would call a Source', who drops a container of microfilm by a bin on Barnes Common and marks an $\mathrm{x}$ with chalk on a billboard nearby, a sign 'that information is waiting to be collected.' His Contact picks up the microfilm and circles the $x$ on the billboard to confirm receipt and sends Source a theatre ticket, specifying the date, time and place for their next meeting.

Source's car pulls up outside Wyndham's Theatre on Charing Cross Road with a teddy bear stuck to the back window. Contact is waiting and they exchange envelopes at a post office counter - money for a secret file taken on Friday, to be copied on Saturday and collected behind a toilet cistern in a cinema on Sunday for re-filing on Monday morning.

Contact does not keep their next rendezvous and tells his controller 'at a certain embassy' he's being watched. He doubts Source is double-crossing him and sketches in their backstory in flashback. Source was first spotted abroad with a British trade delegation, talking indiscreetly about Project $\mathrm{X}$, a new electronic control his firm, Central Electronics, were designing. The conversation was 
bugged, so the enemy set a honey trap, took compromising photographs and blackmailed him into passing them information, paying him $£ 175$ over the next two years. As our narrator Mr Joyce notes:

So this man, by his stupidity, has put himself in the arms of the opposition, and laid himself open to further exploitation...Now, the foreign intelligence net starts on the next stage...finding or planting in the works itself a source of information who will have access to secret documents and drawings.

Joyce looks after Central Electronics 'from a security point of view', so he pays the factory 'an apparently routine visit' and Roberts, their security man, takes him on a very dry and scripted tour. He checks the document registry - who has access and how classified documents are signed in and out and stored; and admonishes staff on lax security - never bring classified documents home, keep keys in the safe rather than an old cigarette tin in your bottom drawer. Joyce has the following exchange with one head of department:

'Do you think the men realise the importance of keeping their mouths shut?' 'Yes, I do.'

'Home as well as in the pub?'

'I make that quite clear... Their job depends on keeping their mouths shut. If security gets broke, that's the end of the firm's contract and their job's gone out the window. Then, who's to pay for the telly?' 'I can see you're a student of human nature. A man after my own heart...'

At the end of his tour, Joyce reveals a security leak concerning Project $\mathrm{X}$, 
alarming senior management:

'It's extremely unpleasant to feel that somewhere in one's own plant there's actually somebody engaged in selling this country's secrets...Is there anything we can do to help?'

Joyce's advice is to 'carry on, as if you didn't know anything. I may know this man's identity but if I tell you who it is, there's just a chance you might give him a hint. We want to give him enough rope and then when the moment's ripe...' As ominous music plays, Joyce goes out to his car and checks his rear view mirror to see the car behind him has a teddy bear stuck to the back window. He gives an icy smile.

Miss James at the COI noted the film 'was RESTRICTED and Security Service have asked that we should not show it indiscriminately... [it should only be seen] by people who have an official reason for seeing it. Distribution would 'be handled entirely through the Security Service,' which meant the film was not listed in the COI catalogue and show prints were controlled directly by MI5. ${ }^{26}$

When asked if spare material should be preserved, she initially wrote yes 'but cannot be used in the usual way as stock shots unless special permission is obtained from Security Service.' She subsequently crossed this out and wrote 'No', asking for all spare material to be destroyed. ${ }^{27}$

The film was edited by Peter Watkins - then starting out at World Wide Pictures - who would go on to make The War Game (1965) for the BBC - a subversive public education film about what to do in the event of a nuclear attack that the BBC found so shocking, they suppressed it for nearly twenty years. ${ }^{28}$ 
It Can't Happen to Me predates by several months the resurgence in spy thrillers in British cinemas. Robert Tronson's The Traitors, released in May 1962, sees a British and American agent team up to penetrate a communist spy ring. The film's publicity claims it 'was so successful that MI5 asked for a copy to study his spy-tailing techniques. ${ }^{29}$

The first Bond film Dr. No premiered in early October and Tronson's next film Ring of Spies, based on the Portland case, was released in March 1964, with Bernard Lee playing both Houghton in Ring of Spies and $M$ in the first eleven Bond films. So these early sponsored training films, written in close collaboration with the Security Service, were ahead of their time in cloaking pressing Cold War security concerns within cautionary tales that used the conventions of the spy genre to realistically depict the true nature and tactics of the Soviet threat. ${ }^{30}$

\section{The Radcliffe Report (1962)}

In the wake of the Radcliffe Report, the COI met with the Security Service on 7 June 1962 to plan a security publicity campaign. An internal COI memo about the meeting, considering a possible film on the subject, has scribbled references to the hit TV series 'Danger Man' (1960) and the annotation: 'Authentic as poss. [lan Fleming?]. ${ }^{31}$

A central element of the campaign would be the production of a booklet on security education, an idea 'first mooted at a meeting of the Defence Board in May 1961'. The Security Service produced a first draft titled 'The Great Game' six months later and circulated its lightly fictionalised case studies of real-life espionage to various ministries 'to promote comment and criticism', drawing this 
response from the Air Ministry:

Any lack of conviction is probably unavoidable because most of us have endured bad films and even worse T.V. plays on these themes, to such an extent that the master spy seems as much a part of bad fiction as the master criminal. ${ }^{32}$

The COI hosted a meeting of the now-formalised Working Group on Security Education on 20 September 1962, chaired by the Kenneth Tolson of the Security Service. Also present were representatives from the Treasury, the War Office, the Foreign Office, the Home Office and the Ministry of Aviation. ${ }^{33}$

The Security Service rejected a COI draft of the booklet in October and commissioned a new draft from 'a member of our staff who is a successful author in his spare time.' The new draft was completed in January 1963 and 'discussed in great detail within the Security Service by an editorial committee', undergoing major revisions 'compatible with not mutilating the author's style'. The COI were 'left in the dark' for over a year until they were sent the final text in October 1963 to help with the final layout. ${ }^{34}$

While Bond author lan Fleming dropped out of the Man from U.N.C.L.E. during this period, citing 'certain pressures,' there is no evidence they included ghost writing the booklet. John Bingham or his protégé, John le Carré, were both 'successful' authors who worked for the Security Service and shared an agent and publisher. As Le Carré moved to MI6 and was posted to Bonn in 1960, Bingham seems the most likely candidate. Le Carré later admitted Bingham was his inspiration for the character of George Smiley. ${ }^{35}$ 
When the COI was finally welcomed back to the Working Group on 12 November 1963, the booklet 'Their Trade is Treachery' was approved, with 100,000 copies to be printed at a cost of $£ 3,525$. A Security Service paper on the booklet sent to the Personnel Security Committee (PSC) at the Treasury to secure final approval, noted:

The production of this booklet is only part of a continuing and extensive campaign in Security Education. Since the beginning of 1963 over 700 Government officials have attended courses run by the Security Service. Departments themselves run courses in which Security Service officers often participate and there are Special Security courses for directors and managers of firms with classified contracts. A film, largely written by the Security Service, is in production under C.O.I. auspices, its object being to underline, mainly for the benefit of Government officials, the security lessons of a hypothetical but realistic espionage case. ${ }^{36}$

\section{Persona Non Grata (1964)}

While production of the booklet was slow, the spy cases kept coming. In September 1962, Admiralty clerk John Vassall was arrested for spying as a Soviet agent. Four months later, Kim Philby defected to Moscow and the Profumo affair soon followed. In September 1963, the ITC anthology series Espionage debuted on ATV, ripping its plots from the on-going scandals. In one early episode, 'The Gentle Spies', an MI5 agent infiltrates a group of anti-nuclear protestors, staging sit-ins and passing out military secrets on the steps of 
Whitehall. ${ }^{37}$

Later that month, the COI commissioned Persona Non Grata 'for the security education of people handling Government confidential information' under the working title 'Security Training Film'. The production folder is fairly thin but the press notes state the film 'took nearly a year to produce', so it seems the script was developed for about six months prior to commissioning. ${ }^{38}$

The film was again produced by World Wide Pictures (James Carr) and directed by David Eady on $35 \mathrm{~mm}$ for a final budget of $£ 22,000$. The press 'chanced on the production' while it was filming in Soho and published brief reports and a rough cut was shown to the Working Group by the end of the year. 39

The final version of Persona Non Grata was shown to interested parties and approved on 18 February 1964, with the proviso that it was 'a restricted film kept under lock and key in the lab vault - all negs and rushes destroyed'. 16mm copies of the film were made available for purchase or hire through the COI Central Film Library. A draft guidance letter to personnel departments said 'it has been produced for use on security education courses and... wherever possible, it should be supported by a talk emphasising the points made in the film.

Departmental Security Officers will be supplied with notes for this talk.' 40

Four days before the final screening, COI Director General Thomas Fife Clark wrote to the Chairman of the PSC asking how press enquiries about the film and booklet should be handled:

As you know, there were stories published... when scenes were being shot 
in Soho [and] the newspapers will know about the completed film as soon as it starts on the Civil Service circuit... My own view is that it would not be really practicable to refuse to show the film to the press...there is a great deal to be said for telling a positive and comprehensive story of what is being done in the Civil Service in using modern publicity methods as one element in tackling a problem which itself has had an enormous amount of publicity. Proof copies of the booklet could be made available to, say, the Defence Correspondents, at a preview of the film together with a note on distribution and other points. ${ }^{41}$

He also suggested allowing BBC and ITV to run extracts from the film on television to help 'stimulate Civil Servants' interest.' On 20 February 1964, the Working Group met again, with representatives from the Treasury and Security Service, and Miss James and Mr Liversidge from the COI:

It was clear from the outset that Security wish to avoid Press publicity when the security film and booklet are ready for use...I stressed that the Press...already knew of the film [as] they had chanced upon it during production...to forestall any idea of secrecy or mystery, and possible unpleasant comment (such as waste of public money), it would be better to describe the campaign to the Press and anticipate questions. Security opposed this, stressing that the object of the campaign was not to reach the public but civil servants and people in industry engaged on Government work...Finally it was agreed that there would be no deliberate attempt to draw the attention of the Press to this campaign, but prepare text which can 
be used by Treasury information section should the Press ask for details. ${ }^{42}$

The next day, the Security Service called COI to confirm that for legal reasons, 'no copies [of the booklet] could go to anyone who is not a civil servant or engaged in government work.' The booklet accused certain individuals of spying and while the Government was protected by privilege if using the booklet 'in the interests of security education' it was not if used 'purely for publicity purposes. ${ }^{43}$

Fife Clark later reported that the Foreign Office 'strongly objected' to press publicity and in any case, running extracts from the booklet was illegal under the Official Secrets Act. It was 'decided that the film should not be shown to the press. ${ }^{44}$

In the press notes, the agreed line on Security Service involvement in the film was that they 'provided advice'. The film 'deals with the threat of espionage' and would not be shown to the public as 'it is designed as part of a security education campaign in the public service...[for] people handling Government confidential information...' It would be made available 'to our allies... as well as to firms holding secret Government contracts, for the security education of personnel having knowledge of classified information. ${ }^{4} 5$

Staff were reminded that 'when dealing with the Press, one must always stress the fact that both film and book are the outcome of the Radcliffe Report (which stressed that one of the greatest dangers to security was the fact that civil servants did not believe that any real threat to national security exists). ${ }^{\prime 46}$

Persona Non Grata starts with Nikolai Popov telling passport control at 
Heathrow he has arrived in London to take over as second secretary at the Soviet embassy. One of his first visitors is David Evans, a freelance journalist for the embassy who recommends Cyril Vining, a 'lost soul' at the Defence department, as a potential source. Evans introduces them at an art gallery opening and Popov befriends the lonely, aspiring writer with a boring desk job and an arrogant boss. ${ }^{47}$

Moscow 'Centre' asks Popov to develop Vining under the codename Mikhail. He invites Vining to the ballet and over lunch, commissions him to write articles about English life for a Russian journal. Popov's seduction of Vining is intercut with the attempts of Evans and a Soviet agent to trace Flight Sergeant Harry Wilson, a former British air attaché in Moscow who might 'be persuaded to cooperate'.

Popov pays Vining handsomely for his articles and becomes his only friend. Over dinner in Vining's bedsit, Popov strikes, using emotional blackmail to ask Vining to get him details of Polaris movements. Spooked by a warning at work to report all contacts with Sino-Soviet bloc officials, Vining almost confesses to his boss before pilfering the documents requested by his new 'friend'.

As Popov tries to activate Flight Sergeant Wilson, Wilson confesses to his boss at the Air Ministry that the KGB caught him 'on the fiddle' in Moscow and blackmailed him into collaborating, and MI5 are called in. Meanwhile, on a Thames boat ride, Vining slips more documents to Popov, who gives him a spy camera to film, rather than steal, documents from now on.

MI5 put Popov under surveillance as he meets Wilson at Chalk Farm station 
and crosses London for another hand-off with Vining in the bear enclosure at London Zoo. Vining is followed home and seen passing microfilm to Popov at two further meetings before MI5 launches Operation Redland to trap them.

A surveillance team follows Vining down Tottenham Court Road to Regent's Park. Two agents pose as a courting couple, Romeo and Juliet, while a Special Branch superintendent lurks nearby to catch Popov and Vining red-handed. Popov is declared 'persona non grata' and deported, and Vining is charged with offences against the Official Secrets Act.

The foreign contact in It Can't Happen to Me and Popov in Persona Non Grata both emerge from Burton Court, an apartment complex in Chelsea presumably where one of the crew lived rather than a Soviet safe house.

As Persona Non Grata began circulation, the Security Service received their first copies of 'Their Trade is Treachery' in early July and the press soon got their hands on a copy as it received favourable mentions in The Times, The Daily Telegraph and The Daily Express in early October. Chapman Pincher called it 'a paperback thriller about the Russian spy machine, compiled by the DirectorGeneral of the Security Service - the real-life "M" of the James Bond novels...It is the most authoritative report on Soviet methods of espionage ever to be allowed outside Intelligence circles. ${ }^{48}$ The foreword states its purpose:

This booklet tells you about the great hostile spy machine that tries to suborn our citizens and turn them into traitors... how to recognize at once certain espionage techniques, and how to avoid pitfalls, which could lead to a national catastrophe or a personal disaster - or both. ${ }^{49}$ 
As Humphreys notes:

The eye-catching colour cover and dramatic title set it aside from run-of-themill government guidance. But the content was even more unusual, reading like security guidance penned by lan Fleming. The pamphlet's tone is journalistic and hard-hitting, and makes use of the very cases - Vassall, Blake and the rest - that had led to the Radcliffe Inquiry in the first place.

As Simon Willmetts and Christopher Moran note, '1965 marked a turning point in the development of spy cinema' with the release of The Spy Who Came in from the Cold (1965) and The Ipcress File (1965), two of the best-known spy films of the sixties. ${ }^{50}$

On 14 June 1965, the COI approached World Wide Pictures to do a followup film to Persona Non Grata with the working title 'Training Film No. 3'. They commissioned a treatment and shooting script for $£ 450$ and exactly three years later, they commissioned a 25-minute film, The Lecture, for just over $£ 14,000 .{ }^{51}$

\section{DOD films}

While The Lecture was in development, the American DOD series of security education films was evolving. Aside from two documentaries on the Abel and Lonsdale cases - The Hollow Coin (1960) and The Secret Underworld (1963) these films were generally narrated dramatizations of 'case histories' pulled from the classified files of military counterintelligence.

They follow a similar pattern - espionage agents preying on the weakness and vulnerabilities of unsuspecting victims, luring them with alcohol, sex, money 
or friendship and blackmailing them into sharing secret information with illicit recordings of embarrassing activity or a signed receipt for 'services rendered' later used to frame them.

The Enemy Agent and You (1964) recaps the Abel-Powers spy swap in Berlin before introducing an American aerospace worker on a month-long posting there. When his room is ransacked, security officers explain the bugging equipment, miniature cameras and infrared photography that can be used to frame him; and the 'weakness, susceptibility to temptation [and] lack of moral fibre' the enemy searches out. In flashback, we see the cautionary tale of an American official, separated from his family, entrapped by a dancer in a local cabaret. Tapes of his night with 'Maria' are then used to demand classified NATO information.

Defense Against the Spy (1967) uses a composite case history of security violations within an electronics firm 'to make you aware of the improbable, unbelievable devices that can be used against your company and you' - highpowered telephoto lenses photographing secret documents from the importexport office across the street, and monitoring conversations with a shotgun directional microphone. A 'telephone repair man' taps a professor's line and plants and wires his chair for sound with a small transmitter, linked to a voiceactivated recorder. 'If you are working in a defense-related area,' the narrator intones:

Your plant must be a strong island of vigilance amid the potential security threats on every side...some day, you too may be on a kind of Candid 
Camera, on the spot in our nation's defense against the spy.

Unlike the British films, these DOD training films, made by the Army Pictorial Center, have no dialogue or location sound, with only music and occasional foley effects augmenting narration. While the COI films are filmed in real locations, the DOD films intercut b-roll or back projections of foreign locations with studio sets.

\section{The Lecture (1968)}

After a three-year delay, The Lecture was finally shot on 35mm over thirteen days from late June to early July 1968 . It was written and directed by James Allen and once again produced by James Carr for World Wide Pictures. Annis James was again the Controlling Officer for $\mathrm{COI}$ and noted 'this film is restricted and should be treated in all respects in the same way as Persona Non Grata.' All rushes were disposed of and the film was kept under lock and key at the lab. The film was approved in late November and made available for restricted distribution the following month. According to the COI synopsis:

The Lecture is a film on protective security concentrating on physical and document security. In order to give dramatic effect to a subject the treatment of which can often be pedestrian, the film is set in KGB headquarters in Moscow...'The Lecture' [is] delivered by an experienced KGB Officer to a class of mainly young KGB Intelligence Officers who are likely to find themselves posted to the United Kingdom. The strengths and weaknesses of the British protective security system are discussed and analysed by the Lecturer and towards the end of his talk he shows a short 
film-within-a-film, purporting to be a reconstruction by the KGB of a spy at work on behalf of the KGB (fictitious case history). ${ }^{52}$

As the Lecturer first enters the classroom, a 'Keep Our Secrets Secret' poster ('Lock It Up') is featured prominently on the door and the lecture begins with a direct reference to the broader security education campaign:

Over the past few years, the enemy have become very much more security conscious...They spend more time on security education, not only lectures like this but also films, publications, posters, they literally advertise security...[As a result], recruitment of agents has become much more difficult.

Over projected film of the London rush hour, he critiques the subject of study: As a result of their bourgeois society and general lack of discipline, the British are naturally unsuspicious, you will find you can move about with relative ease....and photography...would not attract attention...Bourgeois and misguided though it is, you must understand the British way of life if you are to be successful in your task of penetrating and undermining this capitalist system.

Over stock footage of Whitehall, he describes this square mile as the 'nerve centre' of the British capitalist system, the 'seat of government and the target of many of your penetration tasks':

Here are situated the important ministries... a tremendous concentration of 
secret information - not only British secrets but the secrets of their allies... Our primary objective is to develop agents who have authorised access to defence, political, economic and scientific information... If there is what the British call 'a need to know', an official of any rank may have access to secrets...What we really want are photographs of official documents... Some of you will be operating from our legal residency in London... [but] we mount operations outside London [too] - anywhere there's an important secret. Remember what Konon Molody - Lonsdale, as the British knew him - achieved with Houghton and Gee at Portland.

A short film-within-a-film gives a case history of a civil servant codenamed 'Leonid', who befriended a Russian agent at evening classes and exchanged government documents out of a shared interest in foreign affairs. Leonid's expenses were paid but he failed to report his Soviet contact at work, so surveillance photographs of their exchanges looked most incriminating. After being kept 'on ice' for a year, he was pressured into taking documents home and photographing them; and then using a Minox camera and a photocopier to copy documents at work. As security tightened up, Leonid grew nervous and was eventually caught handling a top-secret file he had no need to see:

It was a calculated risk and we ordered him to take it, for he had lost his long-term value. The risk paid off, we got the information but we lost the agent...British security learned there was a leak from Leonid's department ...[and] document registers showed Leonid had access to that file and was the only one who had gained unnecessary access. They set a trap and 
Leonid walked straight into it.

'Comrade Lecturer' admits the security education campaign in recent years has strengthened the British protective security system but 'people just don't imagine that it could happen to them'. He gives the class some rousing final advice:

You are members of the largest, most efficient espionage machine in the world but as our size increases, so does the risk. British counter-espionage have discovered a new weapon - knowledge. Knowledge of our targets and our techniques. They have placed this weapon in the hands of every public servant. We must treat this growing vigilance with the utmost respect, for it is the one weapon that can find our weak spot.

The film ends with one of his agents getting on a London bus, being helped with the right change by a bus conductor and smiling directly to camera. Shortly after its completion, it was mentioned in Chapman Pincher's Daily Express column:

A government film explaining how spies should go about their business is to be shown to all officials who handle secret documents. Its purpose is not to induce them to act as spies but to educate them in how they might be spied on by Russians and other Communist agents. "The Lecture", which cost $£ 15,000$, will not be shown to the public for security reasons. "Diplomats" from the Soviet Embassy might attend. ${ }^{53}$

The following March, it was requested by Major Euston at MI5 for a screening 'at a meeting of the Security Committee at NATO headquarters in Brussels' ${ }^{54}$ 


\section{Any One of Us (1970)}

In 1970, Seafield Head was chosen to direct the last of the British security education films for Verity Films - like World Wide, a trusted producer of government information films since the war. Four years earlier, he had directed $I$ Can't Answer That Question, a short RAF feature about an aircrew held captive in enemy territory, trying to resist 'hard and soft interviewing techniques'. ${ }^{55}$

Sponsored by the Ministry of Defence, Any One of Us was in colour, ran 53 minutes and was completed in November 1970. It's described by the Imperial War Museum as 'the story of a young officer whose weakness of character and love of fast cars and ham radio are exploited by a hostile intelligence agency. He is blackmailed into obtaining classified information and is able to do so because several officers and airmen fail to observe standard security regulations. ${ }^{56}$

The film is shot from the subjective point-of-view of RAF officer Dave Williams, in the style pioneered by Lady in the Lake (1947) and used in Peeping Tom (1960), Rosemary's Baby (1968) and Peep Show (2003-15). Characters address Dave by looking to camera and we only briefly glimpse his reflection in a mirror. The first scene in a pub ends with Williams raising a pint to his mouth (the camera).

Williams is a pilot just back from two years flying in Cyprus and now stuck in a boring desk job at RAF Hampton in Lincolnshire. He's sent to London for a month on a classified training course in security education as the newspapers report an Air Force colonel selling secrets for sex. Before Williams leaves, his wife nags him about their money problems and he carelessly leaks his workplace to a ham-radio operator in Minsk. 
On the training course, Williams fears his ham-radio slip will make him a marked man. He goes drinking one night in Soho and gets 'clipped' in a strip bar for $£ 22$ for champagne with dancer Mia. When a drunk Williams protests he cannot pay, the manager recognises his old squadron tie and settles his debt in exchange for an IOU that lists his name, rank and number.

When Williams is back at base, the manager calls in his favour and sets up a meeting. Two Russians show up in his place, with compromising photographs of Williams' night with Mia and the IOU he signed, now transformed into a receipt for money paid for information - Williams must cooperate or lose his wife and career. Williams cannot believe this is happening to him - he thinks it's a security check but it's real.

Williams gives Peter, his Russian contact, a secret file he was asked to destroy in return for the IOU and negatives. Peter gives him enough money for a down payment on a car and a spy camera to photograph more secret documents. As Williams is sucked in by greed, the Russians demand increasingly valuable information on the radar equipment Williams' unit repairs and its frequencies of operation - 'the crown jewels', Dave calls them, 'I wouldn't get near it.'

He buys a new radio, a new suit for his wife and a new car and is given frequencies and cipher instructions to communicate directly with Moscow 'Centre' by radio. He admonishes staff in the Electronics section of the base for security lapses and uses the information gleaned to steal secrets. But when secret documents are reported missing from registry, he slips up, mistakenly claiming the destruction order for his missing file was signed on a Sunday. He flees to 
London in his new sports car as paranoia takes over.

The RAF open an investigation into Flight Lt. Williams for suspected espionage and as he hands over the evidence to Peter in a dinosaur enclosure at London zoo, he's ambushed by Special Branch officers hiding in the bushes and arrested. Over final shots of his cell, a narrator asks:

What manner of man is this that will betray the trust of his comrades, his family and his country for a few pieces of silver? This was not a rash, quixotic act, nor was it inspired by sincerely held but misguided beliefs. It seems to have been a coldly calculated transaction for money, and yet was this man alone to blame? He was merely the focal point for the exploitation of other men's mistakes - small mistakes of ignorance, carelessness, laziness and moral cowardice. And perhaps the biggest mistake which everyone is prone to - the hopeful belief that it could never happen here.

The film bears similarities to an earlier DOD film, Espionage Target - You! (1964), also directed at military personnel. It reconstructs three case histories of attempted espionage 'by hostile agents of the Sino-Soviet intelligence network.' The presenter/narrator enters the Pentagon and takes case files from a locked safe - cases that show how 'thousands of Sino-Soviet intelligence agents with money to burn' seek out 'unsuspecting targets for exploitation... ensnaring him and then applying pressure to get him to play ball.' A freelance journalist for a Soviet news agency in Munich befriends two servicemen, pays for their help with an article and gets a signed receipt, which he uses to blackmail them into more lucrative assignments involving atomic weapons. One of the men finally reports 
him and the spy ring is broken up.

In another case, a dancer at a Tokyo music hall popular with servicemen, uses 'sex as bait' to collect intelligence from her American boyfriend, Corporal Bissell, on the booze-smuggling operation of Scott, who works for an American electronics firm. Scott cuts a deal with a Chinese agent and signs 'an unitemised receipt designed to pin him forever to a hook' and steal classified data. 'Fully aware that he was travelling a one-way road to treason,' Scott reported the approach and the spy ring was broken up. The message is the same but Seafield's Head's treatment of the material is much bolder and in tune with his time.

\section{Conclusion}

In 1972, the Public Records Office selected the sixties training films for preservation and they are now held by the Imperial War Museum. John Hall, a former director of the COI Film and Television Division, remains ambivalent about their effectiveness:

Taken together the four films are very similar in style and approach. The working out of "spy" plots from which lessons are to be deduced. I am left wondering just how effective they were aside from a general impression of "beware". While I am sure the briefing from the Security Services would have listed a number of "points to be covered"... whether the points would all have been retained and understood is a question which increasingly worried me over the years...not just about security films but about the use 
of film as an effective medium for influencing habits or changes in behaviour. ${ }^{57}$

As James Chapman notes, the critical reaction to the 'Careless Talk Costs Lives' films of the forties was also mixed. The Times admitted they were 'skilfully made' and communicated the 'connection between indiscretion and disaster' but questioned whether their 'sensational quality' strained credulity. Chapman cites a Mass-Observation report on the reception of the films, which shows 'a much higher degree of popularity and response from middle-class people rather than working-class people... which seems to derive largely from the essentially upperand middle-class attitudes of many of the films.' The spies and two of the gossipers in the 'Careless Talk' films were working-class, while the hero of Now You're Talking was 'a factory scientist with a beautiful large house, [who] is killed by the idiocy of a factory worker.' 58

Annis James could never judge the sixties' films' effectiveness because she did not know who the Security Service were showing the films to, but they kept making the films, so they must have thought it was worth it. As Humphreys notes, 'there is no record of a formal assessment of the effectiveness of the [post-Radcliffe] campaign. It is true that the 'spy problem' receded in the second half of the 1960s...[so] the work of the Radcliffe Committee and those who implemented its recommendations [may be partially responsible]. ${ }^{59}$

In the late 1970s, John Hall set up a separate Research Division within the COI Film and Television Division to look into the effectiveness of media campaigns: 'I arranged for a number of films to be tested for retention of 
information and effective influence,' he recalls. 'Memory says I was pretty disappointed at the results...'

In the US, by 1971, there were 'over 2 million industrial employees of 13,000 contractor facilities...entrusted with classified information vital to our national defense efforts' and the 'infinitesimal' number of security violations each year was seen to vindicate security education programs in which training films played a central role in instructing and motivating staff to ensure 'willing, conscientious compliance' with security procedures. ${ }^{60}$

The production of training films on security education dropped off during the late sixties as darker, more cynical representations of counterespionage became commonplace in film and television. As Willmetts notes, CIA director Richard Helms and his predecessor Allen Dulles responded by unsuccessfully pitching movie and television adaptations of Dulles' memoirs and the spy thrillers of $\mathrm{E}$. Howard Hunt. Helms detested the cynical betrayal of agents depicted in films like The Spy Who Came in From the Cold. In the words of his biographer Thomas Powers: 'In Helms's view, the essence of intelligence work was trust. An organization which deceived and sacrificed its own agents with such cold disregard could not stay in business for long...Le Carré was undermining the very bedrock of intelligence, the faith of men in the meaning of their work.' 61 Long after his retirement, as Tinker, Tailor, Soldier, Spy (1979) was midseries on the BBC, John Bingham - the inspiration for George Smiley - wrote a playful letter to le Carré, in which he professed Smiley 'puzzled as to why you have so frequently and harshly attacked his mob, directly in interviews or obliquely in books.' According to his biographer Michael Jago, Bingham felt le 
Carré's depictions of 'brutally inhuman' and duplicitous intelligence services damaged the reputation of the service and staff morale, and encouraged the opposition. 'As far as he was concerned,' le Carré later wrote, 'I was a literary defector who had dragged the good name of the Service through the mud.' ${ }^{62}$

The subsequent success of Tinker, Tailor... and Smiley's People (1982) ensured Smiley lived on in the popular imagination as the dean of counterespionage, ever watchful against the Soviet threat. But as le Carré admitted, he 'turned Bingham the preacher of certainties into Smiley the disciple of doubt', taking his audience into a faceless world beyond the reassuring binaries of the sixties' security education film.

In 1981, Bingham - the likely author of the COI security education booklet 'Their Trade is Treachery' - faced one final indignity. Eighteen years after lauding the booklet as 'a paperback thriller about the Russian spy machine, compiled by the Director-General of the Security Service', Chapman Pincher borrowed its title for a highly controversial book alleging Sir Roger Hollis, MI5 Director-General from the mid-fifties to mid-sixties, had been a Soviet spy since the thirties - the ultimate betrayal. ${ }^{63}$

(8,654 words of text, 870 words of notes, 9,524 total)

\section{Notes}

${ }^{1}$ Christopher Andrew, The Defence of the Realm -The Authorized History of MI5 (London, 2009), 483-502; Hansard, HC Deb 14 November 1962 vol 667 cc 385-523

2 Ibid.

${ }^{3}$ Hansard, Security Procedures (Committee of Inquiry), HC Deb 29 March 1961 vol 637 cc 134450; Hansard, HL Deb 31 October 1962 vol 244 cc 29-36

${ }^{4}$ Hansard, Security Procedures and Practices (Committee), HC Deb 11 May 1961 vol 640 cc 650-5

${ }^{5}$ Hansard, HC Deb 13 June 1961 vol 642 cc 211-7

${ }^{6}$ Security Procedures in the Public Service ('The Radcliffe Report') in CAB C. (62) 51, 16 March 1962, 43-4 
7 Ibid.

${ }^{8}$ Hansard, HC Deb 05 April 1962 vol 657 cc 647

${ }^{9}$ Central Office of Information INF 12/1341, Guidance note for Mr. Deedes from Fife Clark, 23

July 1964, The National Archives, Kew

10 James Chapman, A New History of British Documentary (London, 2015), 129

11 James Chapman, Saints and Avengers: British Adventure Series of the 1960s (London, 2002), 20

12 James Chapman, The British at War: Cinema, State and Propaganda, 1939-45 (London, 1998), 90-1

13 Tony Aldgate and Jeffrey Richards, Britain Can Take it: British Cinema in the Second World War (London, 2007), 96-114

${ }^{14}$ A selection of DOD training films can be viewed at http://bit.ly/2ddtNms

15 James Humphreys, Secrets and Spies: A case study in employee engagement (Woodnewton Associates, 2009) Accessed at http://woodnewtonassociates.co.uk/analysis.html

${ }^{16}$ Chapman (2002), 7, 27

17 James Chapman, The Avengers: Television and Popular Culture during the "High Sixties", in: Anthony Aldgate, James Chapman, and Arthur Marwick (eds.) Windows on the Sixties: Exploring Key Texts of Media and Culture (London, 2000), 37, 40.

18 John Hall, emails to author, 10 and 18 May 2015

19 Patrick Russell, Shooting the Message: John Krish, in: Patrick Russell and James Piers Taylor (eds.) Shadows of Progress: Documentary Film in Post-war Britain (London, 2010), 250-1; Annis James, telephone conversations with author, 18 May and 1 June 2015

${ }^{20}$ Cabinet Office CAB 21/6020, Letter from the Foreign Office to Sir Norman Brook at the Cabinet Office about recent developments concerning the Anti-Communism (Home) Committee, 2 August 1962, TNA

${ }^{21}$ Annis James interview; John Hall correspondence

${ }^{22}$ COI INF 6/2072 - It Can't Happen to Me, TNA

${ }^{23}$ Andrew, 484-8

${ }^{24}$ Chapman (2002), 244; The COI production files also include a commentary dated 27

November 1961, titled 'It Might Have Been You'.

${ }^{25}$ COI INF 6/2072, TNA

${ }^{26} \mathrm{Ibid}$., Annis James interview

27 Ibid.

${ }^{28}$ Watkins confirmed to me by email that he worked as an editor for World Wide Pictures from 1959 to 1963, but he had no memory of working on this film.

${ }^{29}$ Ring of Spies pressbook, included on the Ring of Spies DVD, Network, 2014.

30 James Chapman, Licence To Thrill: A Cultural History of the James Bond Films (London, 1999), 44

${ }^{31}$ COI INF 12/1341, Internal memo, 5 June 1962, TNA

32 Ibid, 'Security Education: Booklet on the Espionage Threat', Security Service paper for the Cabinet Personnel Security Committee, 3 December 1963

$33 \mathrm{Ibid}$, Letter from Thistlethwaite to Thomas, 5 November 1963

${ }^{34}$ Ibid, Security Service PSC memo, 3 December 1963. The COI scribbled two question marks around 'successful author' on their working copy.

35 Thanks to Janice Morphet for her tip on Bingham after my presentation at the Spying on Spies conference, London, 4 September 2015. Cynthia Walker, The Man from U.N.C.L.E.: Ian Fleming's Other Spy, in: Robert Weiner, Lynn Whitfield, Jack Becker (eds.), James Bond in World and Popular Culture: The Films are Not Enough (Newcastle upon Tyne, 2011) 247; Michael Jago, The Man Who Was George Smiley: The Life of John Bingham (London, 2013), 109-112; John

Bingham, My Name is Michael Sibley (London: 2007), vii-xi

${ }^{36}$ COI INF 12/1341, Security Service PSC memo, 3 December 1963, TNA

37 Chapman (2002), 27; 'The Gentle Spies', ITV broadcast, 26 October 1963

38 COI INF 12/1341, Guidance for Use of Press Officers, C.O.I. Film: 'Persona Non Grata', undated, TNA

${ }^{39}$ COI INF 6/2095 - Persona Non Grata, TNA (opened 1995)

40 COI INF 12/1341, Draft D.E.O. Letter to P.V. Departments, 17 April 1964, TNA 
$41 \mathrm{Ibid}$, Letter from Fife Clark to Osmond, 14 February 1964

42 Ibid, Internal COI memo from Liversidge to McMillan, 20 February 1964

$43 \mathrm{lbid}$, Internal memo from Liversidge to McMillan and Tetley, 21 February 1964

$44 \mathrm{Ibid}$, Letter from Fife Clark to Taylor Thompson, Private Secretary to Minister without Portfolio

William Deedes, 23 July 1964

${ }^{45} \mathrm{Ibid}$, Guidance for Use of Press Officers, C.O.I. Film: 'Persona Non Grata', undated

$46 \mathrm{Ibid}$.

47 Persona on Grata (1962) is available on the BFl's InView service

48 'How to avoid being snared into spying', The Daily Express, 1 October 1964

49 Central Office of Information, Their Trade is Treachery (London, 1964, reprinted 2010)

50 Simon Willmetts and Christopher Moran, Filming Treachery: British Cinema and Television's

Fascination with the Cambridge Five, in: Journal of British Cinema and Television 10.1 (2013): 55

${ }^{51}$ COI INF 6/2171 - The Lecture, TNA (opened 2008)

52 Ibid., 'Restricted' Teaching Notes (December 1968) accompanying the film

53 The Daily Express, 7 February 1969

${ }^{54}$ COI INF 6/2171

55 IWM summary, accessed at http://www.iwm.org.uk/collections/item/object/1060022272

56 IWM summary, accessed at http://www.iwm.org.uk/collections/item/object/1060026989

57 John Hall correspondence

${ }^{58}$ Chapman (1998), 91-2

${ }^{59}$ Annis James interview

60 James Reeder, Security Education and Training: Preventive Against Compromise, Defense Industry Bulletin, Winter 1971, 15-18, 22

${ }^{61}$ Simon Willmetts, In Secrecy's Shadow: The OSS and CIA in Hollywood Cinema, 1941-1979 (Edinburgh, 2016); Thomas Powers, The Man Who Kept the Secrets: Richard Helms and the CIA (New York, 1979) 55

62 Jago (2013), 112, 143; Bingham (2007), ix

63 Bingham (2007), xi

\section{Notes on Contributor}

Dr Shane O'Sullivan is a documentary filmmaker and researcher at Kingston

University, London. His three feature documentaries to date (RFK Must Die, Children of the Revolution and Killing Oswald) explore political assassination and terrorism. His video essay Anatomy of a Murder: Sirhan Sirhan and Robert

Kennedy was shortlisted for Best Research Film in the 2016 AHRC Film Awards.

His next film will explore the audiovisual history of espionage through films made 
by and about the security services. 